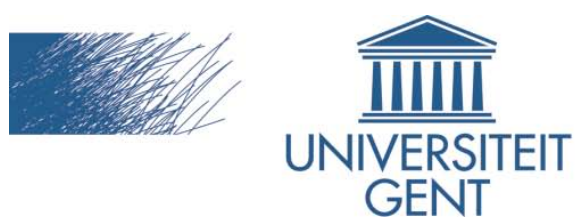

biblio.ugent.be

The UGent Institutional Repository is the electronic archiving and dissemination platform for all UGent research publications. Ghent University has implemented a mandate stipulating that all academic publications of UGent researchers should be deposited and archived in this repository. Except for items where current copyright restrictions apply, these papers are available in Open Access.

This item is the archived peer-reviewed author-version of:

A meta-analysis of the differences in environmental impacts between organic and conventional farming

Mondelaers, Koen; Aertsens, Joris; Van Huylenbroeck, Guido

In: British Food Journal, 111 (10), 1098-1119, 2009.

To refer to or to cite this work, please use the citation to the published version:

Mondelaers, K., Aertsens, J., Van Huylenbroeck, G. (2009). A meta-analysis of the differences in environmental impacts between organic and conventional farming. British Food Journal 111 (10), 1098-1119. 10.1108/00070700910992925 


\title{
A meta-analysis of the differences in environmental impacts between organic and conventional farming
}

\author{
Published as... \\ Mondelaers, K., Aertsens, J., Van Huylenbroeck, G. (2009), "A meta-analysis of the differences in \\ environmental impacts between organic and conventional farming", British Food Journal; Volume:
} 111 (10); pp. 1098-1119;

http://www.emeraldinsight.com/10.1108/00070700910992925

Category: Literature Review

Author keywords: organic; conventional agriculture; meta-analysis; environmental issues

Purpose

This paper aims at comparing the environmental impacts of organic and conventional farming and linking these to differences in management practises. The studied environmental impacts are related to land use efficiency, organic matter content in the soil, nitrate and phosphate leaching to the water system, greenhouse gas emissions and biodiversity.

\section{Design / Methodology / Approach}

The theoretic framework uses the driver-state-response framework and literature data were analysed using meta-analysis methodology. Meta-analysis is the statistical analysis of multiple study results. Data were obtained by screening peer reviewed literature.

\section{Findings}

From our meta-analysis we can conclude that soils in organic farming systems have on average a higher content of organic matter. We can also conclude that organic farming contributes positively to agro-biodiversity (breeds used by the farmers) and natural biodiversity (wild life). Concerning the impact of the organic farming system on nitrate and phosphorous leaching and greenhouse gas emissions the result of our analysis is not that straightforward. When expressed per production area organic farming scores better than conventional farming for these items. However, given the lower land use efficiency of organic farming in developed countries, this positive effect expressed per unit product is less pronounced or not present at all.

\section{Original value}

Given the recent growth of organic farming and the general perception that organic farming is more environment friendly than its conventional counterpart, it is interesting to explore whether it meets the alleged benefits. By combining several studies in one analysis, the technique of meta-analysis is powerful and may allow to generate more nuanced findings and to generalise findings to a wider scope. 


\section{A meta-analysis of the differences in environmental impacts between organic and conventional farming}

\section{Introduction}

The influence of conventional agricultural production on ecosystems has been widely documented (see for example the journal Agriculture, Ecosystems and Environment). In Europe, especially since the 1950s, increase in use of external input factors, e.g. fertilizers and pesticides, has resulted into significant increases in productivity, but simultaneously in a higher environmental pressure. Organic agriculture tries to respond to this challenge by limiting the use of external inputs and integrating several practices which are considered more environment friendly. The organic production system strives at a minimal disruption of the natural equilibrium, and at the same time, high-quality food production by banning residues harmful for human and animal health. Therefore the use of chemical fertilizers, pesticides and genetically modified organisms are prohibited. The organic principles of regulation also stimulate processes of recycling, closed loop systems, and the use of production techniques which allow domestic animals to exhibit species specific behavior. For countries in the EU the regulation is stipulated in EEC regulation 2092/91 and subsequent. In recent years a lot of research has investigated whether the application of the organic farming principles indeed results in differences with respect to environmental pressure. In this article this literature is reviewed and statistically meta-analyzed for possible differences in the impact of organic and conventional farming on nitrate and phosphorous leaching, biodiversity, organic soil content and greenhouse gas emissions. The article is constructed as follows: first a theoretical framework is given, next the applied methodology is introduced, followed by the results and a discussion.

\section{Theoretical framework}

The relation between the agricultural system and the environment is complex. Different analytical frameworks have been constructed to simplify the description and measurement of this relation. The Principles > Criteria > Indicators (PCI) framework (Peeters et al., 2005) for example departs from hierarchical levels to facilitate the definition of indicators enabling the evaluation of the sustainability of agriculture. Another possibility is the transition framework (Meul et al., 2007), in which sustainable development is considered as a complex long term process of change, defining different actions to translate theoretical concepts into practical measures. These actions are in succeeding order: vision development, strategy definition, action and progress monitoring. In this study, we opted for a third possibility, the Driver- State-Response (DSR) framework developed by the OECD (1993) for policy analysis of the state of the environment. The Driver-Pressure-State-ImpactResponse (DPSIR) framework, applied by the European Environmental Agency (EEA, 1999), directly results from this framework. As explained by Platteau et al. (2005), the DPSIR-frame shows the cause-effect relation of agricultural activity on the environment. A certain societal activity, in our case agriculture, is the 'driving force' disturbing the environment. Because agriculture makes use of the environment, it exercises a certain 'pressure' on the environment. Due to this pressure, the environment is characterized by a certain 'state', which, on its turn can influence ('impact') the wellbeing of men, the ecosystem or the economy. Finally, undesired levels of drivers, pressures, states or impacts might trigger a 'response' from the society. At each of these levels, indicators are defined. The DSR and DPSIR framework have been applied a multifold times for the analysis of agricultural systems, for example by COM (2000), Verhaegen et al. (2003), Wustenberghs et al. (2005), Platteau et al. (2006) and Van Steertegem et al. (2006). Also for the specific comparison of organic and conventional farming it has been a well used guiding tool, with most important studies by the Bichel Committee (1998), Stolze et al. (1999) and Hansen et al. (2001). 


\section{Methodology}

As indicated, this paper aims at synthesizing current scientific findings regarding the differences in environmental impact of the organic and conventional farming system. A technique particularly suited to do so is meta-analysis, which is according to Hedges and Olkin (1985) the quantitative synthesis, analysis and summary of a collection of studies. As Arnqvist and Wooster (1995) explain, meta-analysis refers to a specific set of statistical quantitative methods that are designed to compare and synthesize the results of multiple studies. In many ways, the procedures involved are analogous to those of standard statistical methods, but the units of analysis are the results of independent studies rather than the independent responses of individual subjects. Current meta-analysis offers formal methods for most types of statistical inference from a set of studies. Meta-analysis allows the following questions to be addressed: (1) What is the combined magnitude of the effect under study? (2) Is this overall effect significantly different from zero? (3) Do any characteristics of the studies influence the magnitude of the observed effect?

Arnqvist and Wooster (1995) outline the procedure to be followed. (1) all studies addressing a common question or hypothesis are collected. (2) data or test statistics from these studies are transformed into a 'common unit', called 'effect size'. Common measures of effect size are the standardized difference between means of experimental and control groups or the Pearson product moment correlation coefficient. (3) these effect sizes are combined into a common estimate of the magnitude of the effect. (4) using the variation on the effect size results, the significance level of the overall effect size found in (3) is computed. (5) the statistical homogeneity of the effect sizes is calculated. This is conducted to determine whether all studies appear to share a common effect size or not. Finally, (6) the studies used in the meta-analysis are grouped according to various characteristics of the single studies, and the effect sizes between these groups of studies are statistically compared and analysed.

In case it is impossible to estimate the standard deviations of the mean for organic and conventional agriculture, and thus impossible to conduct a meta-analysis, the Sign-test (Abdi, 2007), an alternative (less powerful) method can be applied. This binomial test allows to test whether the frequency of studies with a higher (or lower) value for organic farming significantly differs from the frequency that is found by chance.

Depending on the desired outcome, different output variables can be chosen in meta-analysis. In our case, the response ratio (R), see formula (1), or the ratio between some measured quantity in the experimental (organic) and control (conventional) group, is an interesting measure for the size of the 'experimental' effect (which is the difference between the organic and conventional data point). This $\mathrm{R}$-value estimates the proportionate change that results from an experimental manipulation (Hedges et a., 1999), here the organic farming practices. Hedges et al. (1999) argue to use of the natural log $\left(L_{i}\right)$, see also formula (1), because this value linearises the metric, treating deviations in the numerator the same as deviations in the denominator and resulting in a much more normal sampling distribution of the Log response ratio in small samples.

$R=\overline{X_{E}} / \frac{}{X_{C}}$ and $L_{i}=\ln (R)=\ln \left(\overline{X_{E}}\right)-\ln \left(\overline{X_{C}}\right)$

Under the assumption that $\overline{X_{E}}$ and $\overline{X_{C}}$ are normally distributed, $\mathrm{L}_{\mathrm{i}}$ is approximately normally distributed with mean the real log response ratio and variance given in formula 2 .

$$
v_{i}=\frac{\left(S D_{E}\right)^{2}}{n_{E} \cdot \overline{X_{E}^{2}}}+\frac{\left(S D_{C}\right)^{2}}{n_{C} \cdot \overline{X_{C}^{2}}}
$$


With $\quad S D=$ standard deviation of the experimental resp. control group

$\mathrm{n}=$ number of observations in the experimental resp. control group

According to Hedges et al. (1999), there are two components of variance in the sample log response ratios. One component is due to sampling variation in the estimate for each experiment, the other is due to between experiment variation. Between experimental variation quantifies the degree of true (nonsampling) variation in results across experiments. The statistic $Q$ can be used to test the statistical significance of this second variance component. When this between experiment variance component is significant, the metric denotes a random effect (contrary to a fixed effect), meaning a combination of studies that differ from each other. In that case, caution with the interpretation of the study results is necessary, as well as a correction of the weighting factors (see Hardy and Thompson, 1998).

For our study we based ourselves on literature references fulfilling the following three criteria: 1) peer reviewed; 2) studies dating from after 1992 (year of EEC regulation 2092/91); and 3) (semi) paired samples, this means that organic and conventional data are compared within the same study. Weighting of the references is based upon the possibility of deriving the standard error (s.e.) from the references. Hereby, three cases are distinguished: 1) the s.e. is reported in the study, hence the data point can enter the meta-analysis; 2) the s.e. is not reported, but multiple data points are available in the study, enabling the calculation of a standard deviation based upon the available data which can be entered in the meta-analysis data base; and 3) no s.e. is reported, only a single observation is available. The latter data point has not been retained for the meta-analysis, but is only used in the sign-test.

\section{Results and discussion}

To assess the difference in environmental pressure between organic and conventional agriculture we investigated the following indicators of the environmental state: land use efficiency, organic matter content, nitrate and phosphorous leaching, biodiversity and greenhouse gas emissions. Where relevant and possible, the differences found are linked to differences in driving forces (management practices) between organic and conventional farming.

In annex 1 the analysed references are organized per investigated indicator. Annex 1 furthermore contains studies that are of interest for the topic under study but did not meet our criteria for metaanalysis indicated above.

\section{Land use efficiency}

Land use is an important indicator for natural resource consumption. The land use efficiency indicator is informative because land (especially in densely populated regions) is a scarce good and agriculture has to compete for it with other users (housing, industry, nature reserves). Therefore, policy makers can take differences in land use efficiency into account when they assess environmental impacts expressed per unit area. Some ecologists do contest this approach as they have a more ecocentric rather than a anthropocentric view on ecological problems, partly ignoring that total consumption and production in the end determine the pressure on the ecosystem. For more local problems, such as, e.g. nitrate leaching, the leaching per unit area is most informative, however for more global problems, e.g. greenhouse gas emissions, the pollution per kg food product is more informative.

Table 2 summarizes the results of the meta-analysis for land use efficiency. Following references were retained: Korsaeth and Eltun (2000), Kirchmann and Bergstrom (2001), Knudsen et al. (2006), 
Hansen et al. (2000), Sileika end Guzys (2003), Haas (2002), Torstensson et al. (2006), Taube et al. (2005), Mader et al. (2002), Poudel et al. (2002) and Eltun (1995). Based upon the general results of 10 studies of organic farming in developed countries, a random effect ratio of 0,83 is found, or in other words a land use efficiency of $83 \%$ for organic farming compared with conventional farming. For cereal crops, the random effect indicates a land use efficiency of $81 \%$ for organic farming compared to conventional. When only those studies are combined that report data for a full rotation, organic land use efficiency is approximately $20 \%$ lower than conventional. This latter case is a fixed effect, thus the heterogeneity in the set of studies is no longer significant.

Table 1. Land use efficiency differences between organic and conventional farming expressed as Response ratio (i.e. ratio of organic and conventional output per hectare)

\begin{tabular}{|l|l|l|l|l|l|l|l|}
\hline $\begin{array}{l}\text { Land use } \\
\text { efficiency }\end{array}$ & $\mathrm{N}$ & $\mathrm{n}$ & $\begin{array}{l}\text { No } \\
\text { weighting }\end{array}$ & $\begin{array}{l}\text { Fixed } \\
\text { effect }\end{array}$ & $\mathrm{Q}$ & $\begin{array}{l}\text { Random } \\
\text { effect }\end{array}$ & $\mathrm{Cl}$ \\
\hline All sources & 10 & 70 & 0,814 & 0,841 & $27,1^{*}(24,99)$ & $\mathbf{0 , 8 2 7}$ & $0,76-0,90$ \\
\hline Per rotation & 4 & 47 & 0,802 & $\mathbf{0 , 8 0 6}$ & $8,6(12,59)$ & $/$ & $0,69-0,89$ \\
\hline Cereal crops & 5 & 64 & 0,777 & 0,828 & $11,4^{*}(11,07)$ & $\mathbf{0 , 8 0 9}$ & $0,70-0,93$ \\
\hline
\end{tabular}

$\left(\right.$ ) $=\chi_{d f-1}^{2}, \alpha=0,05 ; N=$ number of studies; $n=$ number of paired observations; $\mathrm{Cl}=$ confidence interval

* Between study variability significant

A recent extensive American meta-analysis by Badgley et al. (2007) collected return ratios from 138 different sources. They report an average organic / conventional yield ratio of $91 \%$ for developed countries for all crops, which is thus higher than our estimate. They furthermore calculated an average organic / subsistence farming ratio of $174 \%$ for developing countries. Based upon their calculations, organic farming would be able to feed the world without bringing extra farmland into use. Rosegrant et al. (2006) tested different conversion scenarios on world scale level. In case of converting $50 \%$ of the European and North American agriculture to certified high input organic agriculture, world production would decrease and prices increase (with approximately 10\%) according to their calculations, which may eventually result in a slight increase in malnourished children in developing countries $(0,3$ to $0,7 \%)$. When converting half of the production in subSaharan Africa to non certified low input organic farming world production would slightly increase (due to the current large share of subsistence farming) and world prices hardly decrease (1 to $2 \%$, given the limited share of Africa in world market production). Because Africa's world market dependency decreases in this scenario, the number of malnourished children will decrease (with 0,8 to $1 \%$ ). Of course such scenarios are highly dependent on the assumptions behind it such as e.g. comparing an semi optimised system with a non-optimised system.

\section{Organic matter content in the soil}

A second environmental state indicator related to resource use is organic matter depletion in the soil. In the European Thematic Strategy for the protection of the soil, soil organic matter content is defined as the key indicator for soil quality because an optimal level of organic matter signifies a good agricultural and environmental soil condition, characterized by reduced erosion, high buffering and filtering capacity and a rich habitat for living organisms (COM, 2002). Stoate et al. (2001) warn for reduced water retention in dry zones and reduced drainage in wet zones when there is a loss of organic matter. Mullier et al. (2006) for example report for Belgium that in the last 20 years the number of parcels with organic matter content below the optimal zone has increased significantly (from 23 to $50 \%$ of the arable land, Mulier et al., 2006). Organic matter content is also important for the $\mathrm{CO}_{2}$ sequestration (Platteau et al., 2005), given that on average 50 to $58 \%$ of organic matter is carbon.

A number of studies don't find convincing evidence for a difference in organic matter content between organic and conventional parcels (Nguyen et al., 1995 for the arable phase; Friedel, 2000; Girvan et al., 2003; Gosling and Shepherd, 2002 and 2005; Bakken et al., 2006 and Cuvardic et al., 2006). A series of other studies (Condron et al., 2000; Fliessbach and Mäder, 2000; Fliessbach et al., 
in press; Mäder et al., 2002; Foereid and Hogh-Jensen, 2004; Hansen et al., 2001; Stolze et al., 2000; Marriott and Wander, 2006; Shepherd et al., 2002; Armstrong-Brown et al., 1995; Clark et al., 1998; Raupp et al., 1995; Loes and Ogaard, 1997, Liebig and Doran, 1999, Wander et al. 1994, Stalenga and Kawalec, 2008, Herencia et al., 2008 and Pulleman et al., 2003 ) report a difference in favour of the organic management practices. A number of these studies can usefully be combined into a metaanalysis (Table 2). Main reasons for non compliance of a number of studies were the absence of a standard deviation, no peer review, no paired comparison, organic matter content monitored during conversion, study dating before 1992 or use of a different technique. Given that organic matter content is mainly expressed as a percentage, the fixed effect value reported in table 3 indicates that the organic matter content on organically managed fields on average exceeds the conventional value with 6,4 percent points. As the $95 \%$ - confidence interval shows (the ratio is not encompassing 1 ), organic matter content on organic plots is significantly higher than on conventional plots. When also accounting for the studies of Pulleman et al. (2003) and Herencia et al (2008), in which very high and significant differences in organic matter are reported, a random effect of 1,12 is found, with $\mathrm{Cl}$ between 1,052 and 1,189. Herencia et al. (2008) report very low organic matter contents prior to the experiment, which might explain the drastic changes in organic matter afterwards.

As main reasons (drivers) for the decrease in organic matter content in conventional agriculture Platteau et al. (2005) and Mulier et al. (2006) refer to: the increase of the plough depth; the lower input of stable organic matter by means of organic manure and soil improvers; the decrease of the practice incorporating crop residues during ploughing; the increase of conversion of grassland into arable land; more stringent manure application rules and even a higher mineralization rate due to climate change. Hodges (1991, in Shepherd et al., 2002) identifies following practices that may explain the better performance of organic farms: mixed farming systems and crop rotation; recycling of manure; use of green manure and the addition of organic manure. Hansen et al. (2001) attribute the better score of organic farming to the more generalised use of capture crops, the recycling of crop residues, the use of organic instead of synthetic fertilizers and relatively more permanent pastures.

Table 2. Differences in organic matter content between organic and conventional farming expressed as Response ratio (i.e. ratio of organic and conventional organic matter content)

\begin{tabular}{|l|l|l|r|r|r|r|rl|}
\hline $\begin{array}{l}\text { Organic matter } \\
\text { content }\end{array}$ & $\mathrm{N}$ & $\mathrm{n}$ & $\begin{array}{l}\text { No } \\
\text { weighting }\end{array}$ & $\begin{array}{l}\text { Fixed } \\
\text { effect }\end{array}$ & $\mathrm{Q}$ & $\begin{array}{l}\text { Random } \\
\text { effect }\end{array}$ & $\mathrm{Cl}$ \\
\hline $\begin{array}{l}\text { Organic (\%) / } \\
\text { Conventional (\%) }\end{array}$ & 7 & 77 & 1,058 & 1,064 & $15,77(16,9)$ & $/$ & 1,046 & - \\
\hline $\begin{array}{l}\text { Organic (\%) / } \\
\text { Conventional (\%) }\end{array}$ & 9 & 103 & 1,128 & 1,091 & $152,71(19,7)$ & 1,118 & $\begin{array}{l}1,052 \\
1,189\end{array}$ \\
\hline
\end{tabular}

()$=\chi_{d f-1}^{2}, \alpha=0,05 ; N=$ number of studies; $n=$ number of paired observations; $\mathrm{Cl}=$ confidence interval

* Between study variability not significant

\section{Nitrate leaching}

Nitrate leaching is one of the main negative externalities of intensive agricultural production. There seems a positive correlation between the increase in productivity and the increase in nitrate leaching (Kirchmann and Bergstrom, 2001). The EU introduced regulation which aims to protect water bodies against pollution induced by nitrates from agricultural sources. Even today, a considerable part of European regions have difficulties to comply. Plateau et al. (2005) report that nitrate concentrations in surface water in Flemish agricultural zones exceed in $40 \%$ of the measurement points the limit of $50 \mathrm{mg} \mathrm{NO}_{3}{ }^{-} / \mathrm{l}$ water imposed by Europe (Nitrate Directive, EC 1991 and Drinking Water Directive, EC 1980). Several authors have studied potential nitrate leaching differences between organic and conventional farming. Table 3 summarizes the response ratios derived from these studies. When taking all studies referred to into account (see Annex 1 ), an average random effects log response ratio of $-0,387$ (or a response ratio of 0,677 ) is found. The leaching is significantly lower for organic farming, which is indicated by the confidence interval (ratio not containing 1 ). The high level of 
heterogeneity between studies (hence the random effect) probably originates from differences in soil types (from sand to clay), region (12 different countries), farming type, research method and the time of measurement. These results should therefore be interpreted with caution. When the studies are grouped based upon farming type or research method, the heterogeneity remains, except for the 4 simulation studies (see Table 3 also).

Table 3. Differences in nitrate leaching between organic and conventional farming expressed as Response ratio (i.e. ratio of organic and conventional nitrate leaching)

\begin{tabular}{|l|l|l|l|l|l|l|l|}
\hline NItrate leaching & $\mathrm{N}$ & $\mathrm{n}$ & $\begin{array}{l}\text { No } \\
\text { weighting }\end{array}$ & $\begin{array}{l}\text { Fixed } \\
\text { effect }\end{array}$ & $\mathrm{Q}$ & $\begin{array}{l}\text { Random } \\
\text { effect }\end{array}$ & $\mathrm{Cl}$ \\
\hline General (kg/ha) & 14 & 116 & 0.703 & 0.745 & $76,7^{*}(36,6)$ & 0,679 & $0,53-0,87$ \\
\hline Arable (kg/ha) & 7 & 76 & 0,618 & 0,839 & $24,1^{*}(16,9)$ & 0,652 & $0,46-0,92$ \\
\hline Mixed (kg/ha) & 6 & 42 & 0,795 & 0,816 & $33,3^{*}(18,3)$ & 0,695 & $0,45-1,08$ \\
\hline Field measure (kg/ha) & 8 & 82 & 0,740 & 0,717 & $53,1^{*}(27,6)$ & 0,690 & $0,50-0,96$ \\
\hline Simulation (kg/ha) & 4 & 28 & 0,576 & 0,850 & $9,00(12,6)$ & $/$ & $0,50-1,45$ \\
\hline
\end{tabular}

( ) $=\chi_{d f-1}^{2}, \alpha=0,05 ; N=$ number of studies; $n=$ number of paired observations; $\mathrm{Cl}=$ confidence interval

Field measure $=$ drainage pipes/porous cups/lysimeters

* Between study variability significant

The calculations for mixed farming, with animal and plant production on the same farm, show a wide confidence interval encompassing 1 , thus for this farm type we cannot conclude that organic farming performs significantly better. The same conclusion holds for the simulation studies, which is interesting given that the calculations show a fixed homogeneous effect. Two of the four simulation studies are conducted by the same research group, which might explain the homogeneity. Three studies expressing nitrate leaching in $\mathrm{mg} / \mathrm{l}$ also find evidence in favor of organic farming (Korsaeth et al., 2000; Haas et al., 2001 and Torstensson et al., 2006).

Besides studying the response ratio, which is a relative measure, it is interesting to look at the absolute value of leaching in both systems and compare it with the $\mathrm{EC}^{\prime} \mathrm{s}$ target value of $50 \mathrm{mg} \mathrm{NO}_{3}{ }^{-} / \mathrm{l}$. Based on 12 studies the weighted average leaching of nitrate is $8,93 \mathrm{~kg} / \mathrm{ha}$ for organic farming and $20,85 \mathrm{~kg} / \mathrm{ha}$ for conventional farming. Whether this results in a nitrate concentration in surface waters above the EC threshold is amongst others function of soil type, precipitation and temperature (Wachendorf et al., 2004). For the Netherlands and Flanders for example, which are two regions with high levels of nitrate leaching, the EC threshold limit is not exceeded when leaching is lower than 34 $\mathrm{kg} \mathrm{NO}_{3}-\mathrm{N} \mathrm{ha}^{-1}$ year $^{-1}$ (Hack-ten Broeke, 2000). Nitrate is a typical local environmental problem, thus measurement in $\mathrm{kg}$ per hectare at farm level or $\mathrm{mg} / \mathrm{l}$ in the river system is appropriate.

In this section's introduction we mentioned the possible link between productivity increase and nitrate leaching. Combining the 6 different studies that also report yields, we again find a significantly smaller nitrate leaching per hectare for organic farming (see Table 5). However, expressed per kg product, the average fixed effect is nearly equal and from the confidence interval we cannot conclude that there is a significant difference. It means that on the basis of this limited set of studies we may conclude that both organic and conventional systems seem to be equally efficient in the creation of agricultural product per unit of nitrate leaching.

The main drivers behind the higher nitrate leaching in conventional farming are the larger amounts of fertilizer application, lower use of green cover crops, lower $\mathrm{C}$ to $\mathrm{N}$ ratio and a higher stocking density per ha.

Table 4. Ratio of organic and conventional nitrate leaching per hectare and per kg product

\begin{tabular}{|l|l|l|l|l|l|l|l|}
\hline NItrate leaching & $\mathrm{N}$ & $\mathrm{n}$ & $\begin{array}{l}\text { No } \\
\text { weighting }\end{array}$ & $\begin{array}{l}\text { Fixed } \\
\text { effect }\end{array}$ & $\mathrm{Q}$ & $\begin{array}{l}\text { Random } \\
\text { effect }\end{array}$ & $\mathrm{Cl}$ \\
\hline General (kg/ha) & 6 & 59 & 0,612 & 0,670 & $9,62(15,50)$ & $/$ & $0,51-0,88$ \\
\hline General (kg/kg product) & 6 & 59 & 0,950 & 0,953 & $12,89(15,50)$ & $/$ & $0,56-1,62$ \\
\hline
\end{tabular}

( ) = $\chi_{\text {df-1, }}^{2} \alpha=0,05 ; N=$ number of studies; $n=$ number of paired observations; $\mathrm{Cl}=$ confidence interval 


\section{Phosphorous leaching}

Due to the low mobility of phosphorous $(P)$ in the soil, in most circumstances, the important sources of P loss are erosion and drainage (Sharpley and Menzel, 1987, Finck, 1992, Edwards and Withers, 1998). However, in some regions with high historical levels of $P$, sandy soils and a flat topography, $P$ leaching might also be an important source of loss (Van de Bossche et al., 2005). Excess levels of soil $P$ are linked with eutrophication of ground and surface waters.

We could only find a limited number of studies (Sileika and Guzys, 2003; Torstensson et al., 2006 and Ekholm et al., 2005) that directly report differences in P leaching (in $\mathrm{kg} / \mathrm{ha}$ ) between organic and conventional farming. The first two studies are long term field trials with drainage pipes, the latter a simulation study. The three studies are inconclusive whether organic or conventional farming performs better (random effects and wide confidence interval containing the value 1 ). The reported levels of leaching are also rather small, thus the relative measure is in this case disinformative. Torstensson et al. (2006) and Sileika and Guzys (2003) find a difference of 0,03kg/ha and 0,04 kg/ha respectively, in favor of conventional farming.

Edwards \& Withers (1998) concluded that the loss of P from agricultural land is controlled by factors that are independent of the annual P surplus. Both Clark et al. (1998) and Djodjic et al. (2005) found a positive correlation between $\mathrm{P}$ balance and $\mathrm{P}$ leaching. Loes and Ogaard (2001) and Hansen et al. (2001) used the $P$ balance as an indicator for $P$ availability. Van de Bossche et al. (2005) used available $\mathrm{P}$ as a proxy for $\mathrm{P}$ leaching, by calculating the soil $\mathrm{P}$ saturation (Psat), i.e. the ratio between the amount of $P$ in the soil and the $P$ absorption capacity of the soil. According to VLM (1997), regions with $\mathrm{P}$ leaching risk have a $\mathrm{P}$ saturation between 30 to $40 \%$, while $\mathrm{P}$ saturated soils have a value above $40 \%$. Van de Bossche et al. (2005) found a Psat of $37 \%$ for organic parcels, which was slightly below the average for the East-Flemish region where the study was conducted (Psat of 39\%). The study contained a high share of organic horticulture sites, which receive an above average $P$ input and also, some farms only recently converted to organic farming. The study of Goulding et al. (2000) reports an Olsen P index of 0 or 1 , which is a P deficit for most crops, for $39 \%$ of organically managed soils versus $15 \%$ for conventionally managed soils in the UK. Haraldsen et al. (2000, Norway) also noticed a decline in available $P$ after conversion to organic farming. Similarly, Oberson et al. (1993) showed significantly lower levels of available $P$ in organic compared to conventional farming systems. Loes and Ogaard (2001) came to the same conclusion during a long term field trial on 5 organic farms. They also showed that the P loss in the top layer could be approximated by use of $P$ balances.

Given the restricted number of studies directly measuring $\mathrm{P}$ leaching, we will also use the $\mathrm{P}$ balance (i.e. $P$ output $-P$ input) as a proxy. Because this balance might be negative, the log response ratio cannot be calculated. We will therefore use the Hedge's g, which is the weighted mean of the standardized difference between the control and experimental group (see Hedges and Olsin, 1985 or Van Zandt, 1998). Both for the $P$ input and the $P$ balance, the measure seems to indicate a lower measure for organic farms, but the confidence intervals are too wide to conclude for a significant difference. The fixed effect for $\mathrm{P}$ output indicates a significantly smaller $\mathrm{P}$ output for organic farms.

Table 5. Ratio of organic and conventional phosphorous input and output per hectare and Hedge's g for the P balance

\begin{tabular}{|l|l|l|l|l|l|c|l|}
\hline Phosphorous leaching & $\mathrm{N}$ & $\mathrm{n}$ & $\begin{array}{l}\text { No } \\
\text { weighting }\end{array}$ & $\begin{array}{l}\text { Fixed } \\
\text { effect }\end{array}$ & $\mathrm{Q}$ & $\begin{array}{l}\text { Random } \\
\text { effect }\end{array}$ & $\mathrm{Cl}$ \\
\hline P input (response ratio) & 12 & 66 & 0,882 & 0,980 & $79,6^{*}(7,81)$ & 0,704 & $0,46-1,07$ \\
\hline P output (response ratio) & 9 & 62 & 0,773 & 0,805 & $13,7(15,50)$ & $/$ & $0,70-0,92$ \\
\hline P balance (Hedge's g) & 8 & 78 & $/$ & $-2,311$ & $1,0(18,30)$ & $/$ & $-4,93-0,30$ \\
\hline
\end{tabular}

()$=\chi_{d f-1}^{2}, \alpha=0,05 ; N=$ number of studies; $n=$ number of paired observations; $\mathrm{Cl}=$ confidence interval 
* Between study variability significant

The different sources of evidence reported here, although inconclusive, seem to indicate a tendency towards lower P leaching levels on organic farms. The most important driver is the lower fertilizer application in organic farming.

\section{Greenhouse gas emission}

The emission of greenhouse gases during production is another negative externality, described into detail in recent documents of IPCC (2007). The Stern Review (2006) adds a more economic focus to the discussion. The three most important greenhouse gases are carbon dioxide $\left(\mathrm{CO}_{2}\right)$, methane $\left(\mathrm{CH}_{4}\right)$ and nitrous oxide $\left(\mathrm{N}_{2} \mathrm{O}\right)$. Each of these gases contributes differently to climate change $\left(1\right.$ ton $\mathrm{N}_{2} \mathrm{O}=$ 310 ton $\mathrm{CO}_{2}$-equivalents and 1 ton $\mathrm{CH}_{4}=21$ ton $\mathrm{CO}_{2}$-equivalents). According to IPCC (2007), agriculture's share in greenhouse gas emissions is approximately $13,5 \%$. These emissions mainly originate from methane fermentation during animal digestion and slurry depots; from nitrous oxide production during biological processes in the soil; from the combustion of fossil fuels $\left(\mathrm{CO}_{2}\right.$ and $\mathrm{N}_{2} \mathrm{O}$ emission) and $\mathrm{CO}_{2}$ emission due to reduction of the soil organic matter content (see previous paragraph).

Dalgaard et al. (2001, Denmark) concluded that conventional farming realizes the highest energy production, while organic farming has the highest energy efficiency. In another publication (Dalgaard et al., 2006) they found a higher emission per unit area for conventional farming. Wood et al. (2006, Australia) concluded based upon a Life Cycle Assessment (LCA) that direct energy use, energy related emissions and greenhouse gas emissions are higher for the organic sample, but indirect contributions are much lower, resulting in an overall substantially higher impact of conventional farming. Leifeld and Fuhrer (2005, Switzerland) link the decrease of agricultural emissions in Switzerland to the increased conversion towards integrated and organic farming. The results of Flessa et al. (2002) indicate that conversion to organic farming reduces the emission per hectare, and a status quo for the emissions per unit product. Olesen et al. (2006) found a lower emission per hectare for organic farms, using a simulation model. Casey and Holden (2006, Ireland) concluded based upon their LCA of conventional and organic farms that the evolution towards more extensive systems results into lower emissions per unit product and simultaneously decreases production. Lotter $(2003$, USA) in his review of organic agriculture in the USA poses that greenhouse gas emissions are lower in organic farming. Syvasalo et al. (2006), who compared $\mathrm{N}_{2} \mathrm{O}$ and $\mathrm{CH}_{4}$ emissions per hectare on organically and conventionally managed parcels, could not find a difference between both systems. De Boer (2003) compared the emission per liter milk calculated in different LCA studies with own data, and warned for the difficulty to compare LCA's given the lack of international standardization. He furthermore remarks that, due to the higher methane production per liter in organic farming, a reduction of the emission compared to conventional farming can only be reached by drastically decreasing carbon dioxide and nitrous oxide emissions. Haas et al. (2001, Germany) found in their LCA per hectare a higher greenhouse gas emission potential for conventional farming, while expressed per ton milk emissions were equal. In the LCA of Cederberg and Mattson (2000, Sweden) emissions per liter were higher in the conventional system. In a recent Dutch report (Bos et al., 2007) greenhouse gas emissions were simulated with model farms. For dairy farms, they found a lower emission for organic farming both per hectare and per liter milk. For arable farming, with soil type being determinative, emissions are lower per unit area but higher per unit product. Gomiero et al. (2008) also focus on the issue of $\mathrm{CO} 2$-emissions in their comparison of organic and conventional farming. As they mainly cite Stölze et al., 2000, they report higher CO2-emissions in conventional farming when expressed per hectare, while per production unit there is a mixed effect. Stalenga and Kawalec (2008) compared the greenhouse gases emission $\left(\mathrm{N}_{2} \mathrm{O}\right.$ and $\left.\mathrm{CH}_{4}\right)$ per hectare of 20 organic farms in a Polish region with the average conventional emission for that region. They found lower $\mathrm{CH}_{4}$ emissions (14\% lower) and much lower $\mathrm{N}_{2} \mathrm{O}$ emissions (only one third of conventional emissions). Finally, Meisterling et al. (2009) calculated the Global Warming Potential (GWP) expressed as g CO2-equivalents per $\mathrm{kg}$ of 
bread for a conventional and an organic product life cycle. In their streamlined LCA, the GWP impact of producing $0,67 \mathrm{~kg}$ of conventional wheat flour (for a $1 \mathrm{~kg}$ bread loaf), not including product transport, is $190 \mathrm{~g} \mathrm{CO}$-eq, while the GWP of producing the wheat organically is $160 \mathrm{~g}$ CO2-eq.

Summarizing, over the different studies, organic farming seems to score equal or better when emissions are expressed per unit area. Per unit product no general direction is noticeable. In Table 6, the results of a limited meta-analysis are reported, as many studies only report single values and no standard deviation. These results indicate a better score for organic farming when expressed per unit area, and no difference when an output measure is used, which supports the qualitative conclusions.

Table 6. Ratio of organic and conventional greenhouse gas emission per hectare and per unit product

\begin{tabular}{|l|l|l|l|l|l|c|l|}
\hline Response ratio & $\mathrm{N}$ & $\mathrm{n}$ & $\begin{array}{l}\text { No } \\
\text { weighting }\end{array}$ & $\begin{array}{l}\text { Fixed } \\
\text { effect }\end{array}$ & $\mathrm{Q}$ & $\begin{array}{l}\text { Random } \\
\text { effect }\end{array}$ & $\mathrm{Cl}$ \\
\hline Greenhouse gas (per ha) & 5 & 112 & 0,608 & 0,572 & $42,5^{*}(21.03)$ & 0,571 & $0,47-0,69$ \\
\hline Greenhouse gas (per kg) & 2 & 53 & 0,899 & 0,930 & $3,6(16,9)$ & $/$ & $0,76-1,13$ \\
\hline Methane (per ha) & 3 & 21 & 0,600 & 0,662 & $0,3(5,99)$ & $/$ & $0,45-0,97$ \\
\hline Nitrous oxide (per ha) & 4 & 31 & 0,860 & 0,624 & $18,5^{*}(14,07)$ & 0,610 & $0,48-0,78$ \\
\hline
\end{tabular}

( ) $=\chi_{\text {df-1 }}^{2}, \alpha=0,05 ; N=$ number of studies; $n=$ number of paired observations; $\mathrm{Cl}=$ confidence interval

* Between study variability significant

What drives the different scores between both farming systems? Organic animal farming has a lower animal stocking rate per hectare, but a higher use of roughage feed per cow, which will influence differences in methane emission. The higher concentrate use in conventional farming increases the carbon dioxide emission. Given the prohibition of chemical fertilizers and pesticides in organic farming, greenhouse gases generated during production of these inputs remain absent. More fuel combustion during mechanical weeding counterweights this effect. In the study of Casey and Holden (2006) regression analysis was used to show the relation between driving factors and emission. They showed a positive correlation between total greenhouse gas emissions per unit area and the feed concentrate dose, the stocking rate and the amount of synthetic fertilizers applied. The latter two also increase the emission per unit life weight. They furthermore showed a very clear correlation between the emission per hectare per year and the production (number of kg produced per hectare per year).

\section{Biodiversity}

For a definition of biodiversity we refer to UN (1992). More biodiversity positively influences the natural buffering function of agrarian areas, which involves recycling of nutrients, control of local micro climate, regulation of local hydrological processes, regulation of undesired organisms, detoxification of noxious chemicals and genetic material for crop improvement (Harlan, 1975 and Altieri, 1994). When studying agriculture and biodiversity it is important to distinguish between agrobiodiversity (breeds used by the farmers) and natural biodiversity (wild life) still present up and around the fields. Both aspects are interesting.

Concerning agro-biodiversity a report from FAO (1998) mentions that centuries of human and natural selection have resulted in thousands of genetically diverse breeds within the major livestock species. These breeds are carefully selected to fit a wide range of environmental conditions, tasks and human needs and forms a rich genetic legacy. Domestic animal diversity, represented by this wide range of breeds, is essential to sustain and enhance the productivity of agriculture. No major livestock or poultry species is in danger of extinction, but numerous breeds within those species are declining in population and size, and many have already disappeared. In Europe, half of all breeds of domestic animals that existed 100 years ago have become extinct, and 43 percent of the remaining breeds are endangered (FAO, 1992). The 1995 edition of FAO's "World Watch List for Domestic Animal Diversity" includes data on 3,882 breeds for 28 domestic species. It concludes that globally $30 \%$ of breeds are classified as endangered and critical. Due to the specific characteristics of the organic farming 
system, other breeds may yield better results and thus organic farming may contribute to the preservation of a wider range of breeds. When we take Belgium as an example, in conventional cattle breeding, the Belgian white blue has become more popular (33\% in 1985 versus $51 \%$ in 2000, NIS), while in organic agriculture the main breeds are Limousin (70\%) and Blonde d'Acquitaine (25\%), due to the ban on systematic Caesareans. The Belgian Red, on the FAO list of threatened bovine species (FAO, 2000) has in the mean time declined from 6\% in 1985 to $1 \%$ in 2000 (TAPAS, 2002). A similar reasoning can be made for plant species used in the agricultural system.

Concerning the impact of agriculture on the natural biodiversity we give an example from Flanders (Belgium) (Nara, 2005; Platteau et al., 2005 and Dumortier et al., 2003). In the past 12 years , 10 out of 20 bird species specific for the agricultural biotope have disappeared or seriously declined, while only 6 made progress. Since 1900, the number of butterfly species has decreased with $25 \%$, while a further $50 \%$ is threatened. Only a very small share of wild plants bound to agricultural land, are found on intensively managed parcels, and none of these species is threatened.

The last few years, four major reviews have focused on the question whether there is a difference in biodiversity contribution between organic and conventional farming. In the review of Soil Association (2000), 9 studies were intensively revised and 14 were summarized. Based upon these, the authors concluded a higher abundance of wild and rare plants, more arthropods, harmless butterflies and spiders and more birds up and around the field. With respect to species richness, they found more wild and rare plant species and more spider species. The most high profile review on this topic is from Hole et al. (2005). They screened 76 studies and report a clear positive effect of the organic management practices on biodiversity. Over the different taxons, they found 66 cases where organic agriculture had a positive effect, against 8 with a negative and 25 with a mixed or no effect. The review of Stockdale et al. (2006) focuses on which management practices influence which species.

A full meta-analysis is conducted by Bengtsson et al. (2005). They calculated the Hedge's g and response ratio for 63 paired studies in total. Their main conclusions are generally a positive effect of organic farming on species richness, with on average $30 \%$ more species compared to conventional fields, and a positive effect on abundance within species (on average $50 \%$ higher). They clearly warn for significant heterogeneity between studies, with for example $16 \%$ of the studies indicating a negative effect of organic farming on species richness.

Hole et al. (2005) extensively described the possible influence of management practices (drivers) on biodiversity. They identify three broad practices that are strongly associated with organic farming as being of particular benefit to farmland biodiversity in general: (1) Prohibition/reduced use of chemical pesticides and inorganic fertilizers; (2) sympathetic management of non-crop habitats and field margins; and (3) preservation of mixed farming.

Some recent studies add to the understanding of potential differences in biodiversity impact. Belfrage et al. (2006) also find higher numbers of both bird diversity and bird abundance on the organic farms than on the conventional farms. They however remark that the largest difference in bird abundance and diversity was found when comparing small and large farms, with high values correlated to small farms. Clough et al. (2007) and Gabriel and Tscharntke (2007) show that the type of management (organic or conventional) might cause considerable shifts in species community structure.

\section{Discussion and conclusion}

From our meta-analysis we can conclude that soils in organic farming systems have on average a higher content of organic matter which is important for a good agricultural and environmental soil condition, characterized by reduced erosion, high buffering and filtering capacity and a rich habitat for living organisms. We can also conclude that organic farming contributes positively to agrobiodiversity (breeds used by the farmers) and natural biodiversity (wild life). 
Concerning the impact of the organic farming system on nitrate and phosphorous leaching and greenhouse gas emissions the result of our analysis is not that straightforward. When expressed per production area organic farming scores better than conventional farming for these items. However, given the lower land use efficiency of organic farming in developed countries, this positive effect expressed per unit product is less pronounced or not present at all.

Focusing on the reasons why a significant difference per hectare is found for the selected environmental effects, it mainly originates from a difference in input intensity (less fertilizer use, lower animal density, no chemical inputs). None of the differences in environmental effects can be attributed to a standalone management practice, it is the combined effects of several modifications to the conventional practices that result into the lower environmental pressure.

The high level of heterogeneity among studies emphasizes the importance of local aspects such as soil type, climate, altitude, legislation and so on and advocates for caution when generalizing these findings. This issue of heterogeneity is at the heart of the problem faced by both conventional and organic production in their relation to the environment. While the organic standards are process oriented, i.e. they describe and limit the conditions under which production is allowed, there is no specific focus on the end product, and therefore also no focus on the site specific environmental bad outputs created during production. This might explain the huge variation found between the studies. Organic rules could have been devised as such that production is optimized while minimizing local environmental impacts. For that it is necessary to monitor how the management practices influence local conditions. Organic farming is, similar to conventional farming, victim of its own success. In every region organic standards are almost alike, to ensure that products labeled 'organic' are produced under the same conditions. This standardization is necessary to allow trade across the globe. Local (or even global) impact on the environment is not specifically accounted for in the cahier the charge. As described in Mondelaers and Van Huylenbroeck (2008), the wave towards globalized meta certification systems makes certification rules less locally adapted. Citing Rigby and Cáceres (2001), "the notion of sustainability is such a site-specific, individualistic, dynamic concept, that arguing that one particular set of codified production practices are its practical expression seems incorrect and likely to attract unnecessary criticism. In this sense, the sustainability concept may be viewed similarly to appropriate technology, in that the appropriateness of particular technologies will also vary temporally and spatially".

Another discussion point relates to the land use efficiency issue. As argued by Glendining et al. (2009), extensification of farming, which is thought to favour non-food ecosystem services, requires more land to produce the same amount of food. The loss of ecosystem services hitherto provided by natural land brought into production is greater than that which can be provided by land now under extensive farming. This loss of ecosystem service is large in comparison to the benefit of a reduction in emission of nutrients and pesticides. Rigby and Cáceres (2001) also take up the issue of productivity in relation to sustainability. They warn for simply equating sustainable agriculture with low-yield farming, as the issue of providing food and fibre for the (growing) non-agricultural population needs also to be addressed. For the question whether to focus on indicators expressed per unit area or per unit product, the systemic level is of importance. The former inform us whether the sustainability of the local ecosystem is under threat, which is important from an environmental perspective. The latter, as they are inversed eco-efficiencies, explain which system creates most output per environmental burden, which is more interesting from a social perspective, given the need for global food security. The indicators expressed per hectare show us that conventional farming is potentially more dangerous for local ecosystem sustainability. The case of nitrate leaching is in this sense informing, as this is typically a local problem. To know whether ecosystem sustainability is really endangered, the indicator scores should be compared with absolute local sustainability thresholds. The indicators expressed per unit product tell us that there is no significant difference between conventional and organic production. To know which system to choose, we 
therefore have to ask whether the current (mainly conventional) agriculture produces enough to feed the growing population, taking into account increasing pressure on land use from both non agricultural human activities, non food agricultural production and nature.

\section{References}

Abdi, H. (2007). The Binomial Distribution - The Binomial and Sign Tests. In: Neil Salkind (Ed.) (2007). Encyclopedia of Measurement and Statistics. Thousand Oaks (CA): Sage.

Arnqvist, G., \& Wooster, D. (1995). Metaanalysis - Synthesizing Research Findings in Ecology and Evolution. Trends in Ecology \& Evolution, 10(6), 236-240.

Badgley, C., Moghtader, J., Quintero, E., Zakem, E., Chappell, M.J., Aviles-Vazquez, K., et al. (2007). Organic agriculture and the global food supply. Renewable Agriculture and Food Systems, 22(2), 86-108.

Bengtsson, J., Ahnstrom, J., \& Wei bull, A.C. (2005). The effects of organic agriculture on biodiversity and abundance: a meta-analysis. Journal of Applied Ecology, 42(2), 261-269.

Belfrage, K., Bjorklund, J., and Salomonsson, L. (2005) "The effects of farm size and organic farming on diversity of birds, pollinators, and plants in a Swedish landscape", Ambio, Vol 34 No 8, 582-8.

Bichel Committee (1998). Report from the Bichel Committee - Organic Scenarios for Denmark. 118 p.

Cederberg, C. and B. Mattsson (2000). Life cycle assessment of milk production -- a comparison of conventional and organic farming. Journal of Cleaner Production 8(1): 49-60.

Clough, Y., Kruess, A., and Tscharntke, T. (2007) "Organic versus conventional arable farming systems: Functional grouping helps understand staphylinid response", Agriculture, Ecosystems \& Environment, Vol 118 No 1-4, 285-90.

COM (2000). Communication from the commission to the council and the European Parliament. Indicators for the Integration of Environmental Concerns into the Common Agricultural Policy. Brussels, 26.01.2000xxx, COM (2000) 20 final.

COM (2002). Communication from the Commission to the council, the European Parliament, the Economic and Social Committee and the Committee of the regions. Towards a Thematic Strategy for Soil Protection. Brussels, 16.4.2002, COM(2002) 179 final.

Cooper, J., C. Leifert, et al. (2007). Handbook of organic food quality and safety. Cambridge, Woodhead Publishing Ltd, Abington; sales@woodhead-publishing.com.

EEA (1999). Environmental indicators: typology and overview. Technical report $n^{\circ} 25$, European Environment Agency, Copenhagen. http://reports.eea.eu.int/TEC25/en/tech_25_text.pdf

Edwards, A.C. and Withers, P.J.A. (1998). Soil phosphorus management and water quality: A UK perspective. Soil Use \& Management, 14, 124-130.

Eltun, R. (1995) "Comparisons of Nitrogen Leaching in Ecological and Conventional Cropping Systems", Biological Agriculture \& Horticulture, Vol 11 No 1-4, 103-14.

FAO (1992) "Livestock Breeds in Developing World Threatened" Press Release, 28 January 1992, p. 1. See also FAO Press Release, 5 December 1995, "New FAO World Watch List for Domestic Animal Diversity Warns: Up to 1,500 Breeds Are at Risk of Extinction," p. 2.

FAO (1998) "Farm Animal Genetic Resources" Special: Biodiversity for food and agriculture. http://www.fao.org/sd/EPdirect/EPre0042.htm; Posted February 1998

Figge, F. and Hahn, T. (2004a). Sustainable Value Added - measuring corporate contributions to sustainability beyond eco-efficiency. Ecological Economics, 48, 173-187.

Figge, F. and Hahn, T. (2004b). Value-oriented impact assessment: the economics of a new approach to impact assessment. Journal of Environmental Planning and Management, 47(6), 921-941.

Gabriel, D. and Tscharntke, T. (2007) "Insect pollinated plants benefit from organic farming", Agriculture, Ecosystems \& Environment, Vol 118 No 1-4, 43-8. 
Glendining, M. J., Dailey, A. G., Williams, A. G., Evert, F. K. van, Goulding, K. W. T., and Whitmore, A. P. (2009) "Is it possible to increase the sustainability of arable and ruminant agriculture by reducing inputs?" Agricultural Systems, Vol 99 No 2-3, 117-25.

Gomiero, T., Paoletti, M. G., and Pimentel, D. (2008) "Energy and environmental issues in organic and conventional agriculture", Critical Reviews in Plant Sciences, Vol 27 No 4, 239-54.

Haas, G., Berg, M. and Köpke, U. (2002), "Nitrate leaching: comparing conventional, integrated and organic agricultural production systems", in Steenvoorden, Joop; Claessen, Frans and Willems, Jaap (ed.), Agricultural Effects on Ground and Surface Waters: Research at the Edge of Science and Society,, International Association of Hydrological Sciences, IAHS Publ. 273, , Oxfordshire, UK., pp.

Hansen, B., H. F. Alroe, et al. (2001). "Approaches to assess the environmental impact of organic farming with particular regard to Denmark." Agriculture Ecosystems \& Environment 83(1-2): 11-26.

Hansen, B., Kristensen, E. S., Grant, R., Hogh-Jensen, H., Simmelsgaard, S. E., and Olesen, J. E. (2000) "Nitrogen leaching from conventional versus organic farming systems - a systems modelling approach", European Journal of Agronomy, Vol 13 No 1, 65-82.

Hedges, L.V., Gurevitch, J., \& Curtis, P.S. (1999). The meta-analysis of response ratios in experimental ecology. Ecology, 80(4), 1150-1156.

Hedges, L.V. and Olkin, I. (1985). Statistical methods for meta-analysis. Academic Press, Orlando, Florida USA.

Herencia, J. F., Ruiz, J. C., Melero, S., Galavis, P. A. G., and Maqueda, C. (2008) "A short-term comparison of organic $v$. conventional agriculture in a silty loam soil using two organic amendments", Journal of Agricultural Science, Vol 146 No, 677-87.

Kirchmann, H. and Bergstrom, L. (2001) "Do organic farming practices reduce nitrate leaching?" Communications in Soil Science and Plant Analysis, Vol 32 No 7-8, 997-1028.

Kleijn, D. and Sutherland, W.J. (2003) "How effective are agri-environment schemes in maintaining and conserving biodiversity?" Journal of Applied Ecology, Vol 40, 947-969.

Knudsen, M. T., Kristensen, I. B. S., Berntsen, J., Petersen, B. M., and Kristensen, E. S. (2006) "Estimated $\mathrm{N}$ leaching losses for organic and conventional farming in Denmark", Journal of Agricultural Science, Vol 144 No, 135-49.

Korsaeth, A. and Eltun, R. (2000) "Nitrogen mass balances in conventional, integrated and ecological cropping systems and the relationship between balance calculations and nitrogen runoff in an 8-year field experiment in Norway", Agriculture Ecosystems \& Environment, Vol 79 No 23, 199-214.

Mader, P., Fliessbach, A., Dubois, D., Gunst, L., Fried, P., and Niggli, U. (2002) "The ins and outs of organic farming", Science, Vol 298 No 5600, 1889-90.

Meisterling, K., Samaras, C., and Schweizer, V. (2009) "Decisions to reduce greenhouse gases from agriculture and product transport: LCA case study of organic and conventional wheat", Journal of Cleaner Production, Vol 17 No 2, 222-30.

Meul, M., Van Passel, S. Nevens, F., Dessein, J., Rogge, E., Mulier, A., Van Hauwermeiren, A. (2007). "An integrated farm sustainability monitoring tool: methodology and application on Flemish dairy farms". Agronomy for Sustainable Development, submitted.

Mondelaers, K. and Van Huylenbroeck, G. (2008) "Dynamics of the retail driven higher end spot market in fresh food", British Food Journal, Vol 110 No 4-5, 474-92.

Oberson, A., Fardeau, J.C., Besson, J.M. and Sticher, H. (1993). "Soil phosphorus dynamics in cropping systems managed according to conventional and biological agricultural methods". Biology and Fertility of Soils 16, 111-117.

OECD (1993). OECD core set of indicators for environmental performance reviews. Environment monographs $\mathrm{N}^{\circ}$ 83. Paris, Organisation for Economic Cooperation and Development, 39p.

Osenberg, C.W., Sarnelle, O., Cooper, S.D., \& Holt, R.D. (1999). Resolving ecological questions through meta-analysis: Goals, metrics, and models. Ecology, 80(4), 1105-1117. 
Peeters A., Bielders C, Hermy M., Mathijs E., Muys B., Vanclooster M. (2005). SPSD II Framework for assessing sustainability levels in Belgian agricultural systems (SAFE). Belgian Science Policy, Brussels, $125 \mathrm{p}$.

Platteau, J., Bas, L., Bernaerts, E., Campens, V., Carels, K., Demuynck, E., Hens, M., Overloop, S., Samborski, V., Smets, D., Van Gijseghem, D., Vriesacker, M., Wustenberghs, H. (2006). Landbouwbeleidsrapport 2005 (LARA). Brussel, Administratie, Departement Landbouw en Visserij, Afdeling Monitoring en Studie, D/2006/3241/155, pp. 240.

Poudel, D. D., Horwath, W. R., Lanini, W. T., Temple, S. R., and van Bruggen, A. H. C. (2002) "Comparison of soil $\mathrm{N}$ availability and leaching potential, crop yields and weeds in organic, low-input and conventional farming systems in northern California", Agriculture Ecosystems \& Environment, Vol 90 No 2, 125-37.

Rigby, D. and Caceres, D. (2001) "Organic farming and the sustainability of agricultural systems", Agricultural Systems, Vol 68 No 1, 21-40.

Rosegrant, M., Sulser, T. and Halberg, N. (2006) Organic agriculture and food security. Paper presented at Joint Organic Congress, Odense, Denmark, May 30-31, 2006.

Sileika, A. S. and Guzys, S. (2003) "Drainage runoff and migration of mineral elements in organic and conventional cropping systems", Agronomie, Vol 23 No 7, 633-41.

Stalenga, J. and Kawalec, A. (2008) "Emission of greenhouse gases and soil organic matter balance in different farming systems", International Agrophysics, Vol 22 No 3, 287-90.

Taube, F., Loges, R., Kelm, M., and Latacz-Lohmann, U. (2005) "A comparative assessment of the performance of organic and conventional arable farming systems on high-quality soils in Northern Germany", Berichte Uber Landwirtschaft, Vol 83 No 2, 165-76.

Torstensson, G., Aronsson, H., and Bergstrom, L. (2006) "Nutrient use efficiencies and leaching of organic and conventional cropping systems in Sweden", Agronomy Journal, Vol 98 No 3, 60315.

Van Steertegem, M. (eindredactie) (2006). Milieurapport Vlaanderen, Mira-t 2006, Leuven, LannooCampus, 272 blz.Verhaegen, E., Wustenberghs, H. \& Lauwers, L. (2003). Elements for "green accounts" for the agricultural sector. Tapas 2002. Environmental aspects of agricultural accounts. Execution report, Centrum voor Landbouweconomie, Brussel, 105 p.

Wander, M. M., Traina, S. J., Stinner, B. R., and Peters, S. E. (1994) "Organic and Conventional Management Effects on Biologically-Active Soil Organic-Matter Pools", Soil Science Society of America Journal, Vol 58 No 4, 1130-9.

Wustenberghs, H, Verhaegen, E., Lauwers, L., De Haes, E.\& Vervaet, M. (2005). Towards integrated economic and environmental agricultural accounts. Tapas 2003, Environmental aspects of agricultural accounts, execution report, Centrum voor Landbouweconomie, Brussel, $98 \mathrm{p}$.

Hardy, R.G. and Thompson, S. (1998). Detecting and describing heterogeneity in meta-analysis. Statistics in medicine, 17, $841-856$.

Hack-ten Broeke, M.J. (2000). Nitrate leaching from dairy farming on sandy soils. Ph.D. Thesis, Wageningen University, The Netherlands.

Wachendorf, M., Büchter, M., Trott, H. and Taube, F. (2004). Performance and environmental effects of forage production on sandy soils. II. Impact of defoliation system and nitrogen input on nitrate leaching losses Grass and Forage Science 59 (1) , 56-68. 


\section{Annex 1: references used in the meta-analysis}

\section{Nitrate leaching}

\section{First screening}

Biro, B., Varga, G., Hartl, W., and Nemeth, T. (2005) "Soil quality and nitrate percolation as affected by the horticultural and arable field conditions of organic and conventional agriculture", Acta Agriculturae Scandinavica: Section B, Soil \& Plant Science, Vol 55 No 2, 111-9.

Condron, L. M., Cameron, K. C., Di, H. J., Clough, T. J., Forbes, E. A., McLaren, R. G., and Silva, R. G. (2000) "A comparison of soil and environmental quality under organic and conventional farming systems in New Zealand", New Zealand Journal of Agricultural Research, Vol 43 No 4, 443-66.

De Neve, S., Dieltjens, I., Moreels, E., and Hofman, G. (2003) "Measured and simulated nitrate leaching on an organic and a conventional mixed farm", Biological Agriculture \& Horticulture, Vol 21 No 3, 217-29.

Eltun, R. (1995) "Comparisons of Nitrogen Leaching in Ecological and Conventional Cropping Systems", Biological Agriculture \& Horticulture, Vol 11 No 1-4, 103-14.

Haas, G., Berg, M. and Köpke, U. (2002), "Nitrate leaching: comparing conventional, integrated and organic agricultural production systems", in Steenvoorden, Joop; Claessen, Frans and Willems, Jaap (ed.), Agricultural Effects on Ground and Surface Waters: Research at the Edge of Science and Society,, International Association of Hydrological Sciences, IAHS Publ. 273, , Oxfordshire, UK., pp.

Hansen, B., Kristensen, E. S., Grant, R., Hogh-Jensen, H., Simmelsgaard, S. E., and Olesen, J. E. (2000) "Nitrogen leaching from conventional versus organic farming systems - a systems modelling approach", European Journal of Agronomy, Vol 13 No 1, 65-82.

Kirchmann, H. and Bergstrom, L. (2001) "Do organic farming practices reduce nitrate leaching?" Communications in Soil Science and Plant Analysis, Vol 32 No 7-8, 997-1028.

Knudsen, M. T., Kristensen, I. B. S., Berntsen, J., Petersen, B. M., and Kristensen, E. S. (2006) "Estimated $\mathrm{N}$ leaching losses for organic and conventional farming in Denmark", Journal of Agricultural Science, Vol 144 No, 135-49.

Korsaeth, A. and Eltun, R. (2000) "Nitrogen mass balances in conventional, integrated and ecological cropping systems and the relationship between balance calculations and nitrogen runoff in an 8-year field experiment in Norway", Agriculture Ecosystems \& Environment, Vol 79 No 23, 199-214.

Kristensen, S. P., Mathiasen, J., Lassen, J., Madsen, H. B., and Reenberg, A. (1994) "A Comparison of the Leachable Inorganic Nitrogen-Content in Organic and Conventional Farming Systems", Acta Agriculturae Scandinavica Section B-Soil and Plant Science, Vol 44 No 1, 19-27.

Ostergaard, H. S., Stougaard, B., and Jensen, C. (1995) "Nitrate Leaching Depending on Cropping Systems", Biological Agriculture \& Horticulture, Vol 11 No 1-4, 173-9.

Pacini, C., Wossink, A., Giesen, G., Vazzana, C., and Huirne, R. (2003) "Evaluation of sustainability of organic, integrated and conventional farming systems: a farm and field-scale analysis", Agriculture Ecosystems \& Environment, Vol 95 No 1, 273-88.

Pimentel, D., Hepperly, P., and Seidel, R. (2005) "Environmental, Energetic, and Economic Comparisons of Organic and Conventional Farming Systems", Bioscience, Vol 55 No 7, 57383.

Sileika, A. S. and Guzys, S. (2003) "Drainage runoff and migration of mineral elements in organic and conventional cropping systems", Agronomie, Vol 23 No 7, 633-41.

Stopes, C., Lord, E. I., Philipps, L., and Woodward, L. (2002) "Nitrate leaching from organic farms and conventional farms following best practice", Soil Use and Management, Vol 18 No s1, 256-63. 
Syvasalo, E., Regina, K., Turtola, E., Lemola, R., and Esala, M. (2006) "Fluxes of nitrous oxide and methane, and nitrogen leaching from organically and conventionally cultivated sandy soil in western Finland", Agriculture Ecosystems \& Environment, Vol 113 No 1-4, 342-8.

Torstensson, G., Aronsson, H., and Bergstrom, L. (2006) "Nutrient use efficiencies and leaching of organic and conventional cropping systems in Sweden", Agronomy Journal, Vol 98 No 3, 60315.

Ulen, B. (1999) "Simulation of nitrate leaching before and after conversion to ecological farming", Biological Agriculture \& Horticulture, Vol 17 No 1, 59-75.

\section{$\mathrm{Kg} / \mathrm{ha}$}

Eltun (1995), Condron et al. (2000), De Neve et al. (2003),Biro et al. (2005), Syvasalo et al. (2006), Sileika and Guzys (2003), Haas (2002), Torstensson et al. (2006), Korsaeth and Eltun (2000), Hansen et al. (2000), Stopes et al. (2002), Knudsen et al. (2006), Pimentel et al. (2005), Pacini et al. (2003)

\section{Comparison per ha \& per kg}

De Neve et al. (2003), Sileika and Guzys (2003), Haas (2002), Torstensson et al. (2006), Korsaeth and Eltun (2000), Hansen et al. (2000)

\section{Simulation}

Condron et al. (2000), De Neve et al. (2003) Knudsen et al. (2006), Hansen et al. (2000)

\section{Lysimeters/drainage pipes}

Eltun (1995), Biro et al. (2005), Syvasalo et al. (2006), Sileika and Guzys (2003), Haas (2002), Torstensson et al. (2006), Korsaeth and Eltun (2000), Stopes et al. (2002)

\section{Arable farming}

Eltun (1995), Biro et al. (2005), Sileika and Guzys (2003), Torstensson et al. (2006), Hansen et al. (2000), Knudsen et al. (2006), Haas (2002)

\section{Mixed farming}

Eltun (1995), De Neve et al. (2003), Syvasalo et al. (2006), Hansen et al. (2000), Stopes et al. (2002), Condron et al. (2000)

\section{Land use}

\section{First screening}

Eltun, R. (1995) "Comparisons of Nitrogen Leaching in Ecological and Conventional Cropping Systems", Biological Agriculture \& Horticulture, Vol 11 No 1-4, 103-14.

Haas, G.; Berg, M. and Köpke, U. (2002), "Nitrate leaching: comparing conventional, integrated and organic agricultural production systems", in Steenvoorden, Joop; Claessen, Frans and Willems, Jaap (ed.), Agricultural Effects on Ground and Surface Waters: Research at the Edge of Science and Society,, International Association of Hydrological Sciences, IAHS Publ. 273, , Oxfordshire, UK., pp.

Hansen, B., Kristensen, E. S., Grant, R., Hogh-Jensen, H., Simmelsgaard, S. E., and Olesen, J. E. (2000) "Nitrogen leaching from conventional versus organic farming systems - a systems modelling approach", European Journal of Agronomy, Vol 13 No 1, 65-82.

Kirchmann, H. and Bergstrom, L. (2001) "Do organic farming practices reduce nitrate leaching?" Communications in Soil Science and Plant Analysis, Vol 32 No 7-8, 997-1028. 
Knudsen, M. T., Kristensen, I. B. S., Berntsen, J., Petersen, B. M., and Kristensen, E. S. (2006) "Estimated $\mathrm{N}$ leaching losses for organic and conventional farming in Denmark", Journal of Agricultural Science, Vol 144 No, 135-49.

Korsaeth, A. and Eltun, R. (2000) "Nitrogen mass balances in conventional, integrated and ecological cropping systems and the relationship between balance calculations and nitrogen runoff in an 8-year field experiment in Norway", Agriculture Ecosystems \& Environment, Vol 79 No 23, 199-214.

Mader, P., Fliessbach, A., Dubois, D., Gunst, L., Fried, P., and Niggli, U. (2002) "The ins and outs of organic farming", Science, Vol 298 No 5600, 1889-90.

Poudel, D. , Horwath, W. , Lanini, W. ,, Temple, S. R., and van Bruggen, A. (2002) "Comparison of soil $\mathrm{N}$ availability and leaching potential, crop yields and weeds in organic, low-input and conventional farming systems in northern California", Agriculture Ecosystems \& Environment, Vol 90 No 2, 125-37.

Sileika, A. and Guzys, S. (2003) "Drainage runoff and migration of mineral elements in organic and conventional cropping systems", Agronomie, Vol 23 No 7, 633-41.

Taube, F., Loges, R., Kelm, M., and Latacz-Lohmann, U. (2005) "A comparative assessment of the performance of organic and conventional arable farming systems on high-quality soils in Northern Germany", Berichte Uber Landwirtschaft, Vol 83 No 2, 165-76.

Torstensson, G., Aronsson, H., and Bergstrom, L. (2006) "Nutrient use efficiencies and leaching of organic and conventional cropping systems in Sweden", Agronomy Journal, Vol 98 No 3, 60315.

\section{Full rotation}

Korsaeth and Eltun (2000), Kirchmann and Bergstrom (2001), Eltun (1995), Sileika and Guzys (2003)

\section{Cereals}

Knudsen et al. (2006), Hansen et al. (2000), Torstensson et al. (2006), Mader et al. (2002), Poudel et al. (2002)

\section{Organic matter}

\section{First screening}

Bakken, A., Breland, T., Haraldsen, T., Aamlid, T. and Sveistrup, T. (2006) "Soil fertility in three cropping systems after conversion from conventional to organic farming", Acta Agriculturae Scandinavica: Section B, Soil \& Plant Science, Vol 56 No 2, 81-90.

Clark, M. S., Horwath, W. R., Shennan, C., and Scow, K. M. (1998) "Changes in soil chemical properties resulting from organic and low-input farming practices", Agronomy Journal, Vol 90 No 5, 66271.

Fließbach, A., Oberholzer, H., Gunst, L., and Mader, P. (2007) "Soil organic matter and biological soil quality indicators after 21 years of organic and conventional farming", Agriculture, Ecosystems \& Environment, Vol 118 No 1-4, 273-84.

Foereid, B. and Hogh-Jensen, H. (2004) "Carbon sequestration potential of organic agriculture in northern Europe - a modelling approach", Nutrient Cycling in Agroecosystems, Vol 68 No 1, 13-24.

Girvan, M. S., Bullimore, J., Pretty, J. N., Osborn, A. M., and Ball, A. S. (2003) "Soil type is the primary determinant of the composition of the total and active bacterial communities in arable soils", Applied and Environmental Microbiology, Vol 69 No 3, 1800-9.

Gosling, P. and Shepherd, M. (2005) "Long-term changes in soil fertility in organic arable farming systems in England, with particular reference to phosphorus and potassium", Agriculture Ecosystems \& Environment, Vol 105 No 1-2, 425-32. 
Nguyen, M. L., Haynes, R. J., and Goh, K. M. (1995) "Nutrient Budgets and Status in 3 Pairs of Conventional and Alternative Mixed Cropping Farms in Canterbury, New-Zealand", Agriculture Ecosystems \& Environment, Vol 52 No 2-3, 149-62.

Pulleman, M., Jongmans, A., Marinissen, J., and Bouma, J. (2003) "Effects of organic versus conventional arable farming on soil structure and organic matter dynamics in a marine loam in the Netherlands", Soil Use and Management, Vol 19 No 2, 157-65.

Herencia, J. F., Ruiz, J. C., Melero, S., Galavis, P. A. G., and Maqueda, C. (2008) "A short-term comparison of organic $v$. conventional agriculture in a silty loam soil using two organic amendments", Journal of Agricultural Science, Vol 146 No, 677-87.

Stalenga, J. and Kawalec, A. (2008) "Emission of greenhouse gases and soil organic matter balance in different farming systems", International Agrophysics, Vol 22 No 3, 287-90.

Stolze, M., Piorr, A., Häring, A. , and Dabbert, S. (2000), The Environmental Impacts of Organic Farming in Europe.

\section{Used in meta-analysis}

Gosling and Shepherd (2005), Nguyen et al. (1995), Girvan et al. (2003), Fliebach et al. (2007), Stolze et al. (2000), Clark et al. (1998), Pulleman et al. (2003)

\section{Phosphorous leaching}

\section{First screening}

Bengtsson, H., Oborn, I., Jonsson, S., Nilsson, I., and Andersson, A. (2003) "Field balances of some mineral nutrients and trace elements in organic and conventional dairy farming - a case study at Ojebyn, Sweden", European Journal of Agronomy, Vol 20 No 1-2, 101-16.

Clark, M. S., Horwath, W. R., Shennan, C., and Scow, K. M. (1998) "Changes in soil chemical properties resulting from organic and low-input farming practices", Agronomy Journal, Vol 90 No 5, 66271.

Condron, L. M., Cameron, K. C., Di, H. J., Clough, T. J., Forbes, E. A., McLaren, R. G., and Silva, R. G. (2000) "A comparison of soil and environmental quality under organic and conventional farming systems in New Zealand", New Zealand Journal of Agricultural Research, Vol 43 No 4, 443-66.

Ekholm, P., Turtola, E., Gronroos, J., Seuri, P., and Ylivainio, K. (2005) "Phosphorus loss from different farming systems estimated from soil surface phosphorus balance", Agriculture Ecosystems \& Environment, Vol 110 No 3-4, 266-78.

Fagerberg, B., Salomon, E., and Jonsson, S. (1996) "Comparisons between conventional and ecological farming systems at Ojebyn - Nutrient flows and balances", Swedish Journal of Agricultural Research, Vol 26 No 4, 169-80.

Gosling, P. and Shepherd, M. (2005) "Long-term changes in soil fertility in organic arable farming systems in England, with particular reference to phosphorus and potassium", Agriculture Ecosystems \& Environment, Vol 105 No 1-2, 425-32.

Gustafson, G. M., Salomon, E., Jonsson, S., and Steineck, S. (2003) "Fluxes of K, P, and Zn in a conventional and an organic dairy farming system through feed, animals, manure, and urinea case study at Ojebyn, Sweden", European Journal of Agronomy, Vol 20 No 1-2, 89-99.

Haas, G., Wetterich, F., and Kopke, U. (2001) "Comparing intensive, extensified and organic grassland farming in southern Germany by process life cycle assessment", Agriculture Ecosystems \& Environment, Vol 83 No 1-2, 43-53.

Langmeier, M. (2002) "Nitrogen fertilizer value of cattle manure applied on soils originating from organic and conventional farming systems ", Agronomie Vol 22 No 7/8, 789-800.

Liebig, M. A. and Doran, J. W. (1999) "Impact of organic production practices on soil quality indicators", Journal of Environmental Quality, Vol 28 No 5, 1601-9. 
Loes, A. K. and Ogaard, A. F. (2001) "Long-term changes in extractable soil phosphorus (P) in organic dairy farming systems", Plant and Soil, Vol 237 No 2, 321-32.

Marinari, S., Mancinelli, R., Carnpiglia, E., and Grego, S. (2006) "Chemical and biological indicators of soil quality in organic and conventional farming systems in Central Italy", Ecological Indicators, Vol 6 No 4, 701-11.

Nguyen, M. L., Haynes, R. J., and Goh, K. M. (1995) "Nutrient Budgets and Status in 3 Pairs of Conventional and Alternative Mixed Cropping Farms in Canterbury, New-Zealand", Agriculture Ecosystems \& Environment, Vol 52 No 2-3, 149-62.

Oberson, A., Fardeau, J.C., Besson, J.M. and Sticher, H. (1993). "Soil phosphorus dynamics in cropping systems managed according to conventional and biological agricultural methods". Biology and Fertility of Soils 16, 111-117.

Reganold, J. P., Palmer, A. S., Lockhart, J. C., and Macgregor, A. N. (1993) "Soil Quality and Financial Performance of Biodynamic and Conventional Farms in New-Zealand", Science, Vol 260 No 5106, 344-9.

Sileika, A. S. and Guzys, S. (2003) "Drainage runoff and migration of mineral elements in organic and conventional cropping systems", Agronomie, Vol 23 No 7, 633-41.

Steinshamn, H., Thuen, E., Bleken, M. A., Brenoe, U. T., Ekerholt, G., and Yri, C. (2004) "Utilization of nitrogen $(\mathrm{N})$ and phosphorus $(\mathrm{P})$ in an organic dairy farming system in Norway", Agriculture Ecosystems \& Environment, Vol 104 No 3, 509-22.

Torstensson, G., Aronsson, H., and Bergstrom, L. (2006) "Nutrient use efficiencies and leaching of organic and conventional cropping systems in Sweden", Agronomy Journal, Vol 98 No 3, 60315.

van Diepeningen, A. D., de Vos, O. J., Korthals, G. W., and van Bruggen, A. H. C. (2006) "Effects of organic versus conventional management on chemical and biological parameters in agricultural soils", Applied Soil Ecology, Vol 31 No 1-2, 120-35.

Watson, C. A., Atkinson, D., Gosling, P., Jackson, L. R., and Rayns, F. W. (2002) "Managing soil fertility in organic farming systems", Soil Use and Management, Vol 18 No s1, 239-47.

\section{$P$ in}

WUR (2007a, 2007b), Torstensson, Aronsson et al. 2006, Ekholm, Turtola et al. 2005, Nguyen, Haynes et al. 1995, Marinari, Mancinelli et al. 2006, Clark, Horwath et al. 1998, Bengtsson, Oborn et al. 2003, Haas, Wetterich et al. 2001, Langmeier 2002.

\section{P out}

WUR (2007a, 2007b), Torstensson, Aronsson et al. 2006, Ekholm, Turtola et al. 2005, Nguyen, Haynes et al. 1995, Marinari, Mancinelli et al. 2006, Clark, Horwath et al. 1998, Bengtsson, Oborn et al. 2003, Haas, Wetterich et al. 2001, Langmeier 2002

\section{P bal}

WUR (2007a, 2007b), Torstensson, Aronsson et al. 2006, Ekholm, Turtola et al. 2005, Nguyen, Haynes et al. 1995, Marinari, Mancinelli et al. 2006, Clark, Horwath et al. 1998, Bengtsson, Oborn et al. 2003, Haas, Wetterich et al. 2001, Langmeier 2002

\section{Greenhouse gases}

\section{First screening}

Casey, J. W. and Holden, N. M. (2006) "Greenhouse gas emissions from conventional, agrienvironmental scheme, and organic Irish suckler-beef units", Journal of Environmental Quality, Vol 35 No 1, 231-9. 
Dalgaard, R., Halberg, N., Kristensen, I. S., and Larsen, I. (2006) "Modelling representative and coherent Danish farm types based on farm accountancy data for use in environmental assessments", Agriculture Ecosystems \& Environment, Vol 117 No 4, 223-37.

de Boer, I. J. M. (2003) "Environmental impact assessment of conventional and organic milk production", Livestock Production Science, Vol 80 No 1-2, 69-77.

Flessa, H., Ruser, R., Dorsch, P., Kamp, T., Jimenez, M. A., Munch, J. C., and Beese, F. (2002) "Integrated evaluation of greenhouse gas emissions (CO2, CH4, N2O) from two farming systems in southern Germany", Agriculture Ecosystems \& Environment, Vol 91 No 1-3, 17589.

Haas, G., Wetterich, F., and Kopke, U. (2001) "Comparing intensive, extensified and organic grassland farming in southern Germany by process life cycle assessment", Agriculture Ecosystems \& Environment, Vol 83 No 1-2, 43-53.

Kaltsas, A. M., Mamolos, A. P., Tsatsarelis, C. A., Nanos, G. D., and Kalburtji, K. L. (2007) "Energy budget in organic and conventional olive groves", Agriculture Ecosystems \& Environment, Vol 122 No 2, 243-51.

Meisterling, K., Samaras, C., and Schweizer, V. (2009) "Decisions to reduce greenhouse gases from agriculture and product transport: LCA case study of organic and conventional wheat", Journal of Cleaner Production, Vol 17 No 2, 222-30.

Olesen, J. E., Schelde, K., Weiske, A., Weisbjerg, M. R., Asman, W. A. H., and Djurhuus, J. (2006) "Modelling greenhouse gas emissions from European conventional and organic dairy farms", Agriculture Ecosystems \& Environment, Vol 112 No 2-3, 207-20.

Petersen, S. O., Regina, K., Pollinger, A., Rigler, E., Valli, L., Yamulki, S., Esala, M., Fabbri, C., Syvasalo, E., and Vinther, F. P. (2006) "Nitrous oxide emissions from organic and conventional crop rotations in five European countries", Agriculture Ecosystems \& Environment, Vol 112 No 23, 200-6.

Syvasalo, E., Regina, K., Turtola, E., Lemola, R., and Esala, M. (2006) "Fluxes of nitrous oxide and methane, and nitrogen leaching from organically and conventionally cultivated sandy soil in western Finland", Agriculture Ecosystems \& Environment, Vol 113 No 1-4, 342-8.

Stalenga, J. and Kawalec, A. (2008) "Emission of greenhouse gases and soil organic matter balance in different farming systems", International Agrophysics, Vol 22 No 3, 287-90.

Wood, R., Lenzen, M., Dey, C., and Lundie, S. (2006) "A comparative study of some environmental impacts of conventional and organic farming in Australia", Agricultural Systems, Vol 89 No 23, 324-48.

\section{Greenhouse Gases per ha}

Haas et al. (2001), Dalgaard et al. (2006), Olesen et al. (2006), Casey and Holden (2006), Kaltsas et al. (2007)

\section{Greenhouse Gases per Life Weight}

Dalgaard et al. (2006), Olesen et al. (2006), Petersen et al. (2006), Syvasalo et al. (2006) 